\title{
Voor en tegen de outsourcing van de financiële functie
}

\author{
Drs. H.A.L.M. van Horn
}

\section{Inleiding}

Het traditionele model van de financiële organisatie in een onderneming is dat deze een eigen financiële afdeling heeft. Gevoed door ontwikkelingen in de Verenigde Staten en versterkt doordat steeds meer in West-Europa werkende ondernemingen zich op Europees niveau gaan herschikken en organiseren, wordt dit model niet langer als vanzelfsprekend gezien. De financieeladministratieve functie is niet meer een noodzakelijk onderdeel van de organisatie van de onderneming waarvoor ze werkt.

Het 'outsourcen' van de financiële en administratieve activiteiten die niet langer tot de kernactiviteiten van de onderneming worden gerekend, begint steeds meer om zich heen te grijpen. Ook in Nederland (Van Horn, 1999a). Over deze ontwikkeling in het bedrijfsleven verschijnen de laatste jaren steeds meer publicaties. Het is daarom tijd om de gebruikte begrippen met betrekking tot dit fenomeen in kaart te brengen en een overzicht te geven van de argumenten voor en tegen de outsourcing van de financiële functie zoals dic worden gehanteerd in de praktijk en in publicaties. In dit artikel zullen wij vervolgens een balans opmaken van deze argumentatie, maar niet nadat wij besproken hebben welke financiële en administratieve activiteiten zich goed lenen voor outsourcing en welke daartoe minder geschikt zijn. Deze bijdrage zal worden afgesloten met enkele opmerkingen over tockomstige

Drs. H.A.L.M. van Horn RA is met sabbatical leave en was bij Shell onder meer werkzaam als directeur van een Accounting House. ontwikkelingen die op het terrein van de outsourcing van de financiële functie zijn te verwachten.

\section{Begripsbepaling}

Onder het outsourcen van de financiële functic verstaan wij het besluit van een onderneming om financiële werkzaamheden niet langer als een activiteit te beschouwen die binnen de organisatie van de eigen onderneming dient te worden uitgevocrd.

Outsourcen kent vier verschijningsvormen: het verzelfstandigen van de financiële functie in een separate, nieuwe onderneming. Deze onderneming blijft tot hetzelfde concern behoren als de ondernemingen waarvoor ze de financiële functie vervult;

het uitbesteden van de financiële functie ('contracting out') aan een zakelijke dienstverlener, ook wel 'full outsourcing' genoemd (Keulemans, 1998, p. 21). Hierbij neemt de onderneming definiticf afscheid van een financiële functie binnen de eigen organisatic; 'co-sourcing' (Keulemans, 1998, p. 21). Dit is een combinatie van de twee voorgaande vormen waarbij de nieuw op te richten onderneming, waarin de financiële functie wordt ondergebracht, een 'joint venture' is van de outsourcende onderneming en een zakelijk dienstverlener;

'multi sourcing.' Hicrbij wordt een nieuwe, separate onderneming opgericht waarin niet alleen de financiële functie wordt ondergebracht, zoals bij verzelfstandiging, maar ook andere ondersteunende bedrijfsprocessen, zoals IT-functie, personeelszaken, vastgoedbeheer, inkoop, logistiek en/of customer services. 
Daarnaast zijn er twee alternatieven voor outsourcing waarbij geen separate onderneming wordt opgericht waar de financieeladministratieve activiteiten in worden ondergebracht:

centralisatie: de financiële en administratieve activiteiten van een aantal werkmaatschappijen van een concern in een land of regio worden gecentraliseerd bij de grootste werkmaatschappij van dit concern in dat land of bij een regionaal hoofdkantoor;

- 'insourcing': de ondernemingsleiding kiest voor de bovengenoemde route van full outsourcing, maar stelt het huidige financieel management ook in staat om een bod te doen. Wordt van dit bod gebruikgemaakt, dan wordt er een nieuwe werkverhouding gecreëerd tussen de financiële functie en de "klantafdelingen' in de onderneming middels een Service Level Agreement (SLA), waarin de financiële producten, tarieven en dergelijke worden geregeld.

Centralisatie als verschijningsvorm van outsourcen komt relatief weinig voor. Van het insourcen van de financiële functie zijn nog geen voorbeelden beschreven, maar het is een fenomeen dat binnen de IT-sector bekendheid heeft gekregen als reactie op het outsourcen van de ITfunctie (Lacity en Hirschheim, 1995, p. 34). Insourcen van de financiële functie kan derhalve een toekomstige ontwikkeling zijn in de financieeladministratieve sector.

In dit artikel zullen wij ons verder concentreren op het outsourcen van de financiële functie, mede omdat het de meest drastische wijze van het reorganiseren van de financiële functie betreft doordat er voor deze functie een separate onderneming wordt opgericht.

In de drie eerst genoemde verschijningsvormen van outsourcen wordt de financiële functie overgenomen door een onderneming die een 'Accounting House' wordt genoemd. De naam 'Regional Accounting Center' komt ook wel voor, maar wij zullen het houden op Accounting House, zijnde de benaming waaronder het onderwerp van dit artikel in eerste instantie bekend is geworden. De naam 'Financial Shared Service Center' wordt in de praktijk ook veel gehanteerd, maar deze naam reserveren wij voor de toepassing waarbij een aantal routinematige financieel- administratieve deelprocessen met een hoog volume wordt geoutsourced (Outram, 1999, p. 15) en niet een geheel ondersteunend bedrijfsproces als accounting, controlling en/of treasury.

Bij 'multi sourcing' wordt de opgerichte onderneming ook wel een 'Competence Center' genoemd.

Onze definitie van het Accounting House (AH) is als volgt: 'Een onderneming met als kernactiviteit het verrichten van operational, financial en management accounting, alsmede andere financiële werkzaamheden ten behoeve van profit- en non-profitorganisaties'.

De ruimte van deze definitie laat het aan de behoeften en mogelijkheden van de praktijk over in welke mate organisaties hun financiële activiteiten wensen te outsourcen. Dat is ook de reden waarom de hier gegeven definitie afwijkt van eerdere en meer beperkt geformuleerde definities (Van Delft Westerhof, 1996, p. 17; Molenkamp c.s., 1998, p. 26). De praktijk kent namelijk al bredere toepassingen dan uitsluitend het outsourcen van routinematige, financieeladministratieve activiteiten met een hoog volume.

Al dan niet in combinatie kunnen de volgende vijf categorieën van activiteiten dan wel verschijningsvormen van het $\mathrm{AH}$ worden onderkend:

- het verrichten van min of meer routinematige administratieve activiteiten, zoals salarisadministratie, facturatie en debiteurenbeheer, reserveringsadministratie, projectadministratie, leaseadministratie enzovoort;

- het voeren van de volledige boekhouding en het verrichten van andere administratieve verplichtingen die zijn verbonden aan het houden van een onderneming;

- het aanleveren van de management-informatie/rapportage ten behoeve van business control;

- het leveren van financiële beleidsondersteuning, zoals investeringsanalyses, kostprijsberekeningen, transferprijsbepaling, koop/huur/ lease-evaluaties, budgettering, opstellen van meerjarenplanning, financiële onderbouwing van strategische keuzes; treasury: liquiditeitsplanning, cash management en cash pooling ('quote/order to cash'), de financiering voor een derde onderneming en het afdekken van financiële risico's (rente, valuta, grondstofprijzen en debiteuren). 
De eerste drie categorieën van activiteiten worden tot nog toe het meest uitbesteed. De uitbesteding van de twee laatstgenoemde categorieën komt vooralsnog incidenteel voor. Overigens zijn er recentelijk pleidooien gehouden voor het outsourcen van de treasury-functie, met name in die gevallen waarbij de onderneming zelf onvoldoende expertise en schaalgrootte heeft om deze functie adequaat te vervullen (Heywood, 1998, p. 34; Schellekens, 1999, p. 28).

\section{De argumenten voor outsourcing van financiële activiteiten}

De literatuur over outsourcen vermeldt de volgende argumenten die het bedrijfsleven in de praktijk hanteert voor het verzelfstandigen in of het uitbesteden aan een $\mathrm{AH}$ van financiële en administratieve activiteiten .

\subsection{Kostenbesparing}

Naar hun aard onderscheiden kunnen er met de introductie van een $\mathrm{AH}$ op vier verschillende wijzen kostenvoordelen worden behaald.

- Door de concentratie van gelijksoortige financiële en administratieve activiteiten van een (groot) aantal ondernemingen in een daartoe gespecialiseerd en geëquipeerd $\mathrm{AH}$ kunnen de voordelen van 'economies of scale' worden behaald: voor het verwerken van eenzelfde totaal aantal financieeladministratieve transacties kan nu worden volstaan met één organisatie en infrastructuur in plaats van meerdere en op verschillende locaties ('duplication of infrastructure'; Fahy en Donovan, 1999, p. 7).

Aan de concentratie in een $\mathrm{AH}$ dient een analyse van het administratieve proces vooraf te gaan: re-engineering van het financieeladministratieve proces (Miller, 1999, p. 46). Dit brengt doublures in administraties aan het licht dan wel administraties die geen actueel doel meer dienen en dus kunnen vervallen. Overigens komt dit vaak voor bij wat oudere en/of grotere organisaties.

De concentratie van administraties in een nieuw $\mathrm{AH}$ leert dat geen van de oude administraties in alle activiteiten de minst efficiënte/ effectieve is, of het tegenovergestelde, in alles de meest geavanceerde is, zowel professioneel als technologisch. In het $\mathrm{AH}$ zal alleen met de 'best practices' worden gewerkt, om zich te kunnen kwalificeren als een 'center of financial excellence'.

Door de separatie van financiën en administratie van de kernactiviteiten (functiescheiding) in een professioneel $\mathrm{AH}$ is men tevens in staat een aanzienlijke reductie op de kostendeclaratie van de externe accountant te realiseren. De interne controle is beter geregeld, concentratie leidt tot uniformiteit van administratieve systemen en de controle kan op één locatie plaatsvinden (Dekker en Wouters, 1995, p. 6).

De tot nu toe bekende implementaties hebben aangetoond dat een kostenbesparing van 30 tot 50 procent over de contractperiode zeer goed realiseerbaar is (Fisher, 1998. p. 40; Jarman, 1998, p. 33; Kersnar, 1998, p. 13; De Vriend, 1997, p. 56).

Lijkt met het voorgaande een beeld te worden geschetst dat het outsourcen van de financiële functie met name geschikt is voor wat grotere en meer gevestigde ondernemingen, de praktijk wijst uit dat ook jonge organisaties die hun activiteiten in een snel tempo in Europa (of anderszins) willen uitbreiden, een $\mathrm{AH}$ wensen te gebruiken als een 'platform for growth'. De systemen en processen zijn namelijk zodanig ontworpen dat de capaciteit goedkoop en zonder redundanties kan worden uitgebreid (Schets en Swagerman, 1998, p. 35). Ook dit is een vorm van besparing van kosten (en investeringen) door 'economies of scale'.

Kostenbesparing behoeft zeker niet 'ten koste' te gaan van de kwaliteit van de financiële functie, met de instelling van een $\mathrm{AH}$ kan juist tegelijkertijd een verbetering van de kwaliteit van het financiële product worden bereikt.

\subsection{Verbetering van de kwaliteit van het financiële product}

Kwaliteit definiëren wij als 'de mate waarin de gebruiker van financiële gegevens zijn vraag om informatie krijgt gehonoreerd', of populair gezegd: 'op zijn wenken wordt bediend'.

In veel organisaties bestaat er een langdurige ontevredenheid over de 'performance' van de financiële afdeling. Er leken geen instrumenten voorhanden te zijn om de status quo te doorbreken. Het gevolg hiervan is dat er directies zijn die 
het outsourcen van de financiële functie gebruiken als middel om de door hen gewenste performance-verbetering van de financiële functic te bewerkstelligen.

De klant wordt weer koning van het financiële product en de boekhouder zijn lakei. Door middel van een Service Level Agreement dwingt de klantonderneming het gewenste kwaliteitsniveau af bij het $\mathrm{AH}$.

Kwaliteit heeft hierbij vier aspecten:

- de door de klant gewenste soort en vorm van de cijfers;

de betrouwbaarheid van de cijfers;

- de snelheid waarmee cijfers beschikbaar komen voor besluitvorming en verantwoording;

- het niveau van het bijbehorende financicel advies.

In vergelijking met de "oude financiële afdeling' zal het $\mathrm{AH}$ door de meer zakelijke verhouding met de klantonderneming geneigd zijn meer te 'investeren' in de relatie met de klant.

De praktijk wijst voorts uit dat bij de overdracht van de boekhouding en dergelijke aan een $\mathrm{AH}$ achterstanden boven water komen die niet cerder zijn gerapporteerd of waargenomen. Een fenomeen dat vooral bij kleinere administraties voorkomt en veelal is ontstaan door gebrek aan menskracht tijdens vakanties/ziekte en/of maand/ kwartaal/jaarafsluitingen.

\subsection{Beheersharheid}

Onderwerpen als 'corporate governance' en de toegenomen belangstelling voor 'business risks' hebben geleid tot de wens van senior management om meer business control te verkrijgen over dochterondernemingen. De invocring van een AH kan daartoc een effectief instrument zijn.

- Met name Noord-Amerikaanse ondernemingen hanteren de centralisatie van hun financiën en administratie in een $\mathrm{AH}$ als middel om hun overzeese werkmaatschappijen strakker aan te kunnen sturen. Een lokale financiële manager heeft veclal de neiging (te) loyaal te zijn aan 'zijn directeur', daar waar de richtlijnen van het Corporate Center als een te strak korset worden gezien.

- Directies van autonome dochterondernemingen zijn veelal voor een (bclangrijk) deel van hun beloning afhankelijk van het financieel resultaat van dic onderneming. Dit resultaat wordt berekend door de 'eigen' financiële afdeling. Hoewel deze bepaling van het resultaat object van (lokale) accountantscontrole zal zijn, kan er toch reden zijn voor de centrale directie om niet alleen organisatorische, maar ook fysieke functiescheiding te creëren door de concentratic van de financiële functics in een separaat te installeren AH. Dit klemt temeer omdat de laatste jaren resultaatsafhankelijke beloning steeds verder en dieper in organisaties wordt doorgevoerd.

In voorkomend geval kan een "track record" van fraude de aanleiding zijn om de financiële afdeling van dochterondernemingen te "onteigenen' en de financiële administratic onder te brengen bij een $\mathrm{AH}$. In een aantal regio's van de niet-westerse wereld kan dit een goed alternatief zijn om langdurige problemen in de bestaande financiële organisatie op te lossen.

Per saldo is een centrale financiëlc functie in de vorm van een $\mathrm{AH}$ voor een corporate center effectiever aanstuurbaar dan een veelheid van geografisch verspreide financiële afdelingen.

\subsection{Standardisatie van bedrijfsprocessen}

Business Process Redesign (BPR) c.q. reenginecring is inmiddels al een aantal jaren een wijdverspreide trend in organisaties, maar implementatic verzandt nog al eens in lokale belangen. Het instellen van een AH kan daarom instrumenteel zijn voor een concern op met name de volgende punten.

- Anno 2000 willen multinationale ondernemingen "global players" zijn. Dit noodzaakt tot standaardisatic van nict alleen de bedrijfsprocessen, maar ook de financiecladministratieve processen, teneinde alle bedrijtsprocessen bij geografische spreiding qua informaticvoorziening gemakkelijk op elkaar aan te laten sluiten.

In weerwil van centraal gepropageerde standaardisatie blijkt bij veel dochterondernemingen een diversiteit van (financiële) software voor te komen (Outram, 1999, p. 14). Implementatie van een $\mathrm{AH}$ brengt deze 
diversiteit glashelder boven tafel en dwingt daarmee tot harmonisatie. Het gevolg hiervan is dat nicuwe releases van software sneller en goedkoper in gebruik kunnen worden genomen.

- Voorts maakt het slechten van verschillen in IT en administratieve afsluitprocedures het mogelijk om maand/kwartaal/jaarcijfers sneller beschikbaar te krijgen voor het Corporate Center.

Indien aan de orde, vergemakkelijkt harmonisatie ook de implementatic van ERP-software (ERP = Enterprise Resource Planning) of verlaagt de hieraan verbonden implementatickosten aanzienlijk.

Bij de implementatie van een $\mathrm{AH}$ komen valak inefficiënties in de financiceladministratieve processen aan het licht die bij nadere analyse blijken te worden veroorzaakt door inefficiënties in het voorliggende, niet-financiële. bedrijfsproces, dan wel in de daarbij behorende procedures. Ongewild kan dit noodzaken tot een al dan nict gedeeltelijke 'business process redesign', die kan leiden tot besparingen die soms een veelvoud zijn van de aanvankelijk beoogde besparingen op de kosten van de financiële functie.

Een grondig en goed gedocumenteerd proces van re-engineering wordt in de literatuur unaniem als een 'key success factor' voor het welslagen van het outsourcen van de financiële functic gezien (o.a. Miller, 1999, p. 46; Jarman, 1998, p. 33).

Door ondernemingen te ontdoen van supportfuncties is men ook beter in staat om de grondvorm van de onderneming te vereenvoudigen. Hierdoor wordt de onderneming niet alleen slanker, maar kan deze zich ook beter aanpassen aan veranderende marktomstandigheden.

\subsection{Optimale structunr: flexibiliteit contimuiteit en mogelijkheden}

Als gevolg van de schaal waarop het $\mathrm{AH}$ zal functioneren ten opzichte van de individuele, kleinere en veclal gefragmentecrde financiecladministratieve afdelingen van ondernemingen, biedt de vorming van een $\mathrm{AH}$ de kans om een optimale structuur te creëren die cen betere garantic geeft voor de flexibiliteit en de continuï- teit van de financiële organisatie en daarnaast meer mogelijkheden voor financiële dienstverlening verschaft.

Door zijn omvang en meer gevaricerde klantenkring zal het $\mathrm{AH}$ tlexibeler kunnen zijn in zijn capaciteit en de verwerking van het werkaanbod. Klantondernemingen kunnen hierbij denken aan:

het gemakkelijk integreren van nieuwe acquisities ("platform of growth");

het eenvoudig deconsolideren van verzelfstandigingen en te verkopen dochterondernemingen:

het beter opvangen van al dan niet seizoenmatige pieken en dalen in het werkaanbod;

- het soepeler accommoderen van langdurige afwezigheid door bijvoorbeeld ziekte of vakantie binnen de bestaande personeelsbezetting.

De laatste twee punten vormen belangrijke argumenten omdat ze impliceren dat het $\mathrm{AH}$ meer zekerheid biedt met betrekking tot de continuïteit van de financiële dienstverlening.

De schalalgrootte waarop het $\mathrm{AH}$ zal opereren maakt het tevens mogelijk een meer effectieve en robuuste organisatie en infrastructuur neer te zetten die meer mogelijkheden biedt. Het wordt nu rendabel te investeren in een geavanceerde en efficiënte IT-infrastructuur en de inzet van gespecialiseerde (financiële) expertise, wat roor de individuele financiële functies te kostbaar zou zijn geweest (Edur, 1999, p. 33). Tevens wordt het beter mogelijk om de kwetsbaarheid van kritische systemen te verminderen (Molenkamp c.s., 1998, p. 34).

Naast de garantie voor een betere continuïteit van de financiële bedrijfsvocring, biedt het $\mathrm{AH}$ flexibiliteit in extreme vorm: om welke reden dan ook kan de klantonderneming zijn Service Level Agreement (de overeenkomst op basis waarvan de werkzalamheden worden verricht) met het Alt op regulicre wijze opzeggen.

\subsection{Professionaliteit}

Het outsourcen van de financiële functic wordt nogal eens geïnitieerd door senior nietfinancied management uit cen langdurige onvrede met het niveau en de professionaliteit 
van de financiële functic. Bovendien komen veranderingen in de financiële functie doorgaans niet autonoom tot stand, maar worden "geforceerd" door andere bedrijfsfuncties, zoals IT, Marketing of Engineering en/of door ontwikkelingen buiten de onderneming. Het AII zal zich genoodzaakt zien een zelfstandig bestaan op te bouwen en zal zich dus terdege realiseren dat het wordt afgerekend op de professionaliteit van zijn dienstrerlening. Werd in het verleden een minder presterende financiële functic getolereerd of kon deze zelfs een machtspositic opbouwen, nu ontstaat er een andere, meer zakelijke. verhouding met de gebruiker van financiële informatic.

Van de professionalisering van de financiële functic in een $\mathrm{AH}$ kunnen de volgende aspecten worden genoemd.

Door zijn meer gespecialiseerde focus zal het AH geneigd en in staat zijn om sneller en professioneler in te spelen op actucle ontwikkelingen (Euro, Millennium, E-commerce, fiscaal, verslaggeving).

In tegenstelling tot de uitbestedende onderneming heeft het $\mathrm{AH}$ financiën en administratic als kernactiviteit: dat betekent dat in het $\mathrm{AH}$ een diepere en bredere financiële rakkennis zal zijn geconcentreerd waar de klantonderneming een beroep op kan docn. Omvang en transfer van financiële kennis zijn hierdoor beter gewaarborgd.

Dit laatste argument zal het $\mathrm{AH}$ ook in staat stellen beter gekwalificeerd personeel aan te trekken, ondat het appelleert aan een grotere groep potentiële kandidaten waardoor beter kan worden geselecteerd.

- Door zijn schaal van opereren en financiële focus biedt het $\mathrm{AH}$ ook betere loopbaan- $\mathrm{en}$ trainingsmogelijkheden voor het personeel dat is meegegaan naar het nicuwe All.

- De voorgaande vier punten hebben in de praktijk reeds bewezen dat ze leiden tot beter gemotiveerd personeel, wat vervolgens weer leidt tot een betere werkprestatie. Doordat een AH roor meerdere ondernemingen werkt en daardoor een gevariecrder ervaring en kennis opdoct. zowel in de breedte als in de diepte, is cr sprake van cen "organisational learning" dic niet wordt bereikt bij ecn solitair werkende financiële functic (Dussauge en Garrette, 1999, p. 44).
De "tucht van de marki' zal de AH-organisatic dwingen continu het uiterste te presteren. Voor de klant van de financiële informatic wordt het gewenste product van de financiële functic bespreckbaar. In de nieuwe context moet er naar die klant worden geluisterd en alert worden gereageerd.

\subsection{Strategische oremegingen}

De keuze on de financiële functie te outsourcen kan het gevolg zijn van de autonome keuze van een onderneming om zich te concentreren op zijn kernactiviteiten, maar kan ook zijn ingegeven door ontwikkelingen van buiten de onderneming. bijvoorbeeld in zijn bedrijfskolom, als gevolg van Supply Chain Management (SCM).

De strategische keuze van een onderneming om zich geheel op zijn kernactiviteit te richten, kan het besluit met zich brengen om de ondersteunende bedrijfsprocessen, zoals catering. huisdrukkerij, facility management (kantoordiensten/gcbouwenbeheer), ITafdeling, inkoop, logistick, customer services (call centre), juridische dienst, accountantsdienst, personeelszaken en de financiële afdeling te outsourcen. Simons (1999. p. 293) stipuleert dat succesvolle managers strategische grenzen leggen bij producten en diensten die nict direct bijdragen tot het succes van de kerncompetentic van de onderneming. Voorts blijkt dat bij toenemende verticale integratic ondernemingen het efficiënter vinden om niet-kernactiviteiten te outsourcen (Brealey en Myers, 2000, p. 944).

Overigens zijn beide opmerkingen te herleiden tot het actuele denken in kerneompetenties. dat ervan uitgaat dat coneentratic leidt tot een optimale waardecreatie door de onderneming als geheel. Dit betekent dat hicrmee het outsourcen van de financiële functic zijn strategisch perspectief heeft gekregen.

\subsection{Overige argumenten}

De volgende argumenten worden ook als voordeel van outsourcing van de financiële functie genoemd:

cen meer optimale inzet van lyet werkkapitaal (Schulman c.s., 1999, p. 16): "cash pooling"; de mogelijkheid on voor het $\Lambda H$ de fiscaal 
meest gunstige vestigingsplaats te kiezen

(King c.s., 1998, p. 33).

\section{Argumenten tegen het outsourcen van de financiële functie}

Het merendeel van de tot nu toe verschenen publicaties rond het fenomeen van de outsourcing van de financiële functie noemt uitsluitend de roordelen van outsourcing. Ze komen dan ook zonder uitzondering uit de hoek van de zakelijke dienstverleners. Er zijn echter ook argumenten tegen het outsourcen van de financiële functie te verdedigen.

\subsection{Investeringsuitgaven en kosten.}

In paragraaf 3.1 zijn de kostenvoordelen besproken die te behalen zijn met de outsourcing van de financiële functic. Maar een oud Hollands gezegde houdt ook hicr stand: de kost gaat voor de baat uit.

Bij het opzetten van een $\mathrm{AH}$ moet men onder meer rekening houden met de volgende kostenposten:

cenmalige projectkosten. Te denken valt aan kosten van consultants (change, tax, IT, legal, re-engineering), projectleiding, communicatic, overtolligheidsregelingen, werving, training, verhuizingen enzovoort. De omvang van deze post zal mede worden bepaald door de keuze het project in eigen beheer uit te vocren, of, dat men in aanzienlijke mate van zakelijke dienstverleners gebruik zal maken; investeringsuitgaven ten behoeve van een nieuwe kantoorlocatic voor het $\mathrm{AH}$. de inrichting $\mathrm{cn}$ de IT (hard- en software) $\mathrm{cn}$ communicatic-infrastructuur. Dit kan een substantiële post zijn omdat men er doorgaans voor kiest geen 'oude spullen' mee te nemen, want het nieuwe $\mathrm{AH}$ moet een nieuwe professionele en klantgerichte bedrijfscultuur hebben;

het nieuwe AH zal zelf ook een eigen begroting van kosten (en opbrengsten) krijgen als 'running company";

men moet er voorts beducht voor zijn dat er geen doublures van kosten ontstaan doordat klantondernemingen toch nog bepaalde administratieve activiteiten in stand proberen te houden nadat het outsourcen van de financiële functie officieel zijn beslag heeft gekregen.
De eenmalige projectkosten en investeringsuitgaven zijn aanzienlijk hoger dan men in eerste instantic geneigd is te denken. Ze zullen moeten worden gecompenseerd door de in paragraf 3.1 genoemde kostenbesparingen.

\subsection{Ingrijpend veranderingsproces}

Wil men optimaal gebruikmaken van de te realiseren voordelen zoals die zijn genoemd in paragraaf 3, dan dient senior management zich zeer goed te realiseren dat een ingrijpend veranderingsproces noodzakelijk is. Het is geen 'kaasschaaf-methode', maar het outsourcen van de financiële functic is een grondige afstemming van het financiceladministratieve proces op de procesdoelstellingen van de kerncompetentics van de onderneming (zie in dit verband ook: Hammer en Stanton. 1999, p. 115). Daarom dient het veranderingsproces professioneel te worden gemanaged op straffe van een aantal afbreukrisico's (Van Horn, 1999c, p. 64). De belangrijkste hicrvan is dat de continuïteit en de integriteit van de financiële verantwoording en managementinformatie van de betrokken ondernemingen in gevaar kunnen komen.

\subsection{Weerstand}

Het ingrijpend karakter van het veranderingsproces moet zeker nict alleen in technische zin worden begrepen. In de praktijk is gebleken dat het outsourcen van de financiële functic door betrokkenen persoonlijk als zeer ingrijpend wordt ervaren en mogelijk zelfs als destructief (Irvine, 1998. p. 46). Niet alleen door de betreffende financieel medewerkers, die zich in de zekerheid van hun (loop)baan zien bedreigd, maar ook door de directies van ondernemingen die 'hun' financiële afdeling kwijtraken. Dit kan tot weerstand en verlies van motivatie en moreel leiden (Kurtz en Duncan. 1998, p. 48)

\subsection{Personeelsverloop}

Het voorgaande kan tevens tot ongewenst personeelsverloop leiden. waarmee cruciale knowhow verdwijnt. Dit kan ontstaan wanneer het project te lang duurt, zonder voldoende voortgang en met onvoldoende communicatic. Dit leidt tot onzekerheid bij de betrokken financiële medewerkers. met als gevolg dat veelal de 
besten een werkkring elders accepteren.

Er kan nog een tweede soort personeelsverloop ontstaan. Wanneer de oprichting van een nieuw AH noodzaakt tot verhuizen, dan haken veel van de betrokken medewerkers af. Hierdoor is het nodig nieuw, vaak hooggekwalificeerd personeel te werven, wat zeker in de beginfase en ook daarna noodzakelijk is in verband met de vereiste meertaligheid. De praktijk wijst echter nog al eens uit dat wanneer het AH een paar jaar functioneert, de uitdaging er voor dit nieuwe personeel vaak af is (Miller, 1999, p. 48).

\subsection{Onvoldoende bedrijfskennis}

Het extern aangetrokken, doorgaans jonge personeel voor het nieuwe $\mathrm{AH}$ zal tekortschieten in kennis van bedrijf, branche en werkervaring. Dit kan worden opgelost door de nieuwe werknemers enige tijd mee te laten lopen met het bestaande financiële personeel van de uitbestedende onderneming, maar als dit personeel juist zijn baan dreigt te verliezen door de outsourcing, dan is succes van de inwerkperiode bij voorbaat welhaast uitgesloten

\subsection{Complexe omgeving}

De omgeving van de eigen financiële afdeling is beschermd en vertrouwd: dat is het gebouw van de eigen onderneming. Voor het management en het personeel van het nieuwe AH ligt dat anders: zij krijgen te maken met een buitenwereld die complex is door verschillen in taal, cultuur, valuta en allerlei nationale regelgevingen op het gebied van accounting, belastingen, vennootschaps- en arbeidswetgeving in de diverse landen waarvoor wordt gewerkt (Dekker en Wouters, 1995, p. 6). De conclusie die hier uit moet worden getrokken, is dat er in het $\mathrm{AH}$ wel met minder personeel kan worden gewerkt ten opzichte van de oude situatie, maar dat het wel beter opgeleid en weerbaarder dient te zijn.

\subsection{Afstand}

Als vestigingsplaats van het $\mathrm{AH}$ wordt doorgaans een locatie gekozen die voor het totaal van de klantenkring als optimaal wordt beschouwd, maar die niet optimaal behoeft te zijn voor de individuele klantonderneming. Soms ook wordt een locatie gekozen die fiscale faciliteiten biedt, bijvoorbeeld België in verband met zijn regeling voor 'coördinatie centers', of lerland. Hoewel er tegenwoordig een veelheid aan elektronische communicatiemiddelen beschikbaar is, blijft ook op financieel terrein behoefte aan periodiek persoonlijk overleg. Dit betekent dat de ontstane fysieke afstand door directies van klantondernemingen als een bezwaar kan worden ervaren, of als bezwaar wordt gehanteerd.

\subsection{Meerwerk}

Wordt er gekozen voor full outsourcing (uitbesteding aan een zakelijke dienstverlener) waarbij gunning heeft plaatsgevonden aan de laagste inschrijver, dan blijkt dat iedere extra activiteit die aan het AH wordt gevraagd en die buiten het contractuele pakket van het Service Level Agreement valt additioneel in rekening wordt gebracht. Indien er in het SLA geen goede afspraken voor eventueel meerwerk zijn gemaakt. dan kan dit een kostbare aangelegenheid worden indien men de omvang van het werkpakket bij de concipiëring van het SLA niet goed heeft ingeschat (Orr, 1998, p. 66).

\subsection{Contractor risk}

Kiest men voor full outsourcing van de financiële functie, dat wil zeggen de financiële functie wordt overgenomen door een $\mathrm{AH}$ van een zakelijke dienstverlener, derhalve een derde, dan bestaat de mogelijkheid dat deze derde op enig moment tijdens de contracttermijn niet voldoet aan zijn contractuele verplichtingen. Een risico dat men niet loopt bij een 'inhouse' financiële afdeling.

\section{Welke financiële activiteiten outsourcen en welke niet?}

Een solide keuze voor het outsourcen van de financiële functie wordt bereikt doordat het senior management met zijn ondernemingsstrategie een visie heeft ontwikkeld op taak en doelstellingen van de financiële functie. Deze kan worden geconcretiseerd in het opstellen van een Corporate Finance Control Framework (CFCF) voor de eigen onderneming als geheel (Van Horn, 1999b, p. 41-42). 
Het 'lukraak' uitbesteden van een probleem roept alleen maar (nog meer) problemen van (management) control op. Voordat het senior management een projectvoorstel voor de implementatic van een $\mathrm{AH}$ maakt, moet men eerst bedenken hoe het proces van management control in de onderneming moet plaatsvinden en hoe men het financiële proces daar wenst in te passen. Vervolgens vergelijkt men de gewenste wijze van management en financial control met de actuele situatie en werkwijze. Uit deze verschillenanalyse kunnen aangrijpingspunten naar voren komen voor een haalbaarheidsonderzock naar outsourcing, walarbij gesignaleerde lacunes en doublures worden opgelost.

Het $\mathrm{AH}$ moet passen in het strategisch kader van de uitbestedende onderneming, maar moet ook passen in diens CFCF. Dit CFCF moet het mandaat en het kader aangeven waarin outsourcing van financiële activiteiten mogelijk is $\mathrm{cn}$ tevens de grenzen duidelijk maken die het senior management wenst te leggen in de 'in housc'- en de 'out house'-verantwoordelijkheden op financieel gebied. Elders hebben wij dit reeds meer modelmatig uitgewerkt en aangegeven welke financiële activiteiten zich voor outsourcing lenen en welke niet (Van Horn, 1999b. p. 43-45).

Hieraan kan nog het volgende worden toegevoegd. Als we de begrippen van Emmanucl c.s. (1998, p. 125) overnemen, lijkt het voor de hand te liggen om te signaleren dat "accounting for programmed activities' zich beter leent voor outsourcing dan 'accounting for non-programmed activities'. Dit louter doordat bekend is, en daardoor omschrijfbaar, wat er gedaan moet worden en hoc. Dit leidt er in de praktijk toe dat de in paragraaf 2 genoemde eerste drie categorieën (namelijk meer routinematige accountingwerkzaamheden) het meest worden uitbesteed. Financiële beleidsondersteuning kan natuurlijk ook worden uitbesteed, maar dit zal door het "non-programmed'-karakter doorgaans a tarief plaatsi inden. wat het minder beheersbaar maakt. Aan de andere kant moet financiële beleidsondersteuning dan wel controlling vaak weer terugvallen op de "boekhouding", om haar werk goed te kunnen doen. Een strikt onderscheid is dus niet zomaar te maken, wat ervoor zou pleiten om de financiëlc functic in zijn geheel te outsourcen. want dan is duidelijk waar de verantwoording voor de financiële activiteiten ligt.

De keuzesituatic is overigens veel helderder wanneer wij een concern beschouwen dat een groot aantal gelijksoortige dochterondememingen kent. Hebben deze ondernemingen dezelfde kernactiviteit (het zijn bijvoorbeeld allemaal verkoopdochters of overeenkomstige fabricagelocaties), maar elk een eigen financiële functie, dan is concentratic en outsourcing van al dic zelfstandige administraties in een separaat $\mathrm{AH}$ voor de hand liggend.

Tot slot kan de huidige kwalitatieve opbouw van de financiële functic en/of de omvang daarvan zodanig anders zijn dan senior management op korte termijn voorstaat, dat de beslissing tot outsourcing wordt genomen om een acuut probleem op te lossen.

Welke financiële activiteiten lenen zich niet voor outsourcing?' Impliciet is deze vraag met het bovenstaande al beantwoord. 'Accounting for non-programmed activities" lijkt lastiger uit te besteden doordat de activiteiten moeilijker in een SLA zijn te omschrijven. Voor financiële beleidsondersteuning bij strategieformulering, investeringsevaluaties en soortgelijke onderwerpen waarbij specifieke bedrijfs- en branche-expertise doorslaggevend kan zijn voor de kwaliteit van het financieel advics, zal men doorgaans niet voor outsourcing kiczen. De reden hiervoor kan ook de gewenste confidentialiteit van de expertise betreffen.

Twijfelt men over de vraag welke activiteiten voor outsourcing geschikt zijn, dan is altijd de volgende oplossing mogelijk. Men kan de scope van werkzaamheden van het $A H$ stapsgewijze uitbreiden door bijvoorbeeld ecrst de meer routinematige administraties en de bockhouding over te dragen. Binnen een (vooraf) bepaald migratiepad volgen dan in een latere fase de andere onderdelen van de financiële functie. In de desbetreffende organisatorische setting kan dit een betere acceptatic opleveren bij het betrokken personeel en de ondernemingen om wier financiële functie het gaat. 


\section{De afweging van de argumenten voor en tegen het outsourcen van de financiële functie}

$\mathrm{Na}$ het voorgaande dringt zich een klemmende vraag op: moet ik als ondernemer mijn financiële afdeling outsourcen? Zo ja, in zijn geheel, of uitsluitend bepaalde activiteiten en welke activiteiten dan wel? Zo nee, zijn daar goede argumenten voor?

De vraag is voor de financieel directeur of controller nog lastiger te beantwoorden. Want stelt hij niet zijn eigen functie ter discussie door met het idee voor outsourcing te komen?

Er zijn nog meer (lastige) vragen te stellen. Is het concept beter geschikt voor grotere ondernemingen dan voor kleinere ondernemingen, of is juist het omgekeerde het geval? Of: is outsourcing beter geschikt voor ondernemingen die een groot aantal gelijksoortige werkmaatschappijen of filialen hebben, dan voor een onderneming die een uniek bedrijfsproces bezit?

Het outsourcen van de financiële functie is nog een pril fenomeen. De consequentie hiervan is dat er nog geen systematisch onderzoek is gedaan naar de validiteit van de argumenten voor en tegen outsourcing, hoe zwaarwegend de argumenten zijn bij de besluitvorming van ondernemingen tot implementatie, en vervolgens de ultieme toets: hebben de gehanteerde argumenten in de praktijk tot het beoogde resultaat geleid.

Voor het argument van de kostenbesparing lijkt voldoende steun te bestaan, rapportages van individuele ondernemingen (Singleton-Green, 1996, p. 50) en onderzoeken van twee van de zogenoemde 'big five'-kantoren lijken dit te onderbouwen (Fahy en Donovan, 1999, p. 7; De Vriend, 1997, p. 53). De onderzoeksresultaten gaan zelfs zover dat Amerikaanse implementaties gemiddeld 10 procent meer kostenbesparing blijken op te leveren dan West-Europese (Jarman, 1998, p. 33), dit vanwege het fragmentarische karakter van de EU-regio op grond van cultuur, taal, regelgeving en valuta.

Men kan zich afvragen of de afweging voor outsourcing überhaupt in zijn algemeenheid is te maken. Vooralsnog lijkt in aanvang het outsourcen vooral populair te zijn bij grotere ondernemingen met meerdere vestigingen in meerdere landen. Daar staat weer tegenover dat ook een onderneming als de BBC met een onbetwist uniek bedrijfsproces zijn financiële functie heeft geoutsourced, overigens om strategische redenen.

De beste methode om inzicht te krijgen in de bedrijfseconomische voors en tegens is het maken van de som van deze afwegingen. Dat betekent dat men voor de eigen onderneming evalueert welke argumenten van toepassing zijn en daar een bedrag aan toekent; positief of negatief, afhankelijk van het soort argument. Tegen de achtergrond van de bespiegelingen in de voorgaande paragrafen is het voor een weloverwogen besluitvorming nuttig om niet alleen een bedrag per argument te geven, maar ook een kwalificatie van de strategische relevantie. Daarnaast is het raadzaam om een inschatting te geven van het risico van het wel of niet realiseren van het betreffende argument.

Dit betekent dat voorlopig de veronderstelling is dat de afweging om tot outsourcing van de financiële functie over te gaan uitsluitend individueel per onderneming kan worden gemaakt. Een onderbouwing voor deze stelling is de observatie dat ondernemingen die een efficiënte en professionele financiële functie kennen waarvan het functioneren niet ter discussie staat, niet snel aanleiding zien om de outsourcing-vraag aan de orde te stellen. Het blijkt ook dat ondernemingen die voor outsourcing hebben gekozen, dit besluit hebben genomen omdat de financiële functie voor hen dermate ontoereikend was geworden, dat een minder abrupt veranderingsproces geen reële optie was.

Overigens blijken de meeste nadelen, net zo goed als de voordelen, in de praktijk van relatieve aard te zijn. Dat wil zeggen, onderkent men ze tijdig, voordat aan het veranderingstraject wordt begonnen, dan blijken ze meestal oplosbaar door adequate maatregelen: technologisch, professioneel en/of door een goede (wederzijdse) communicatie.

\section{Verwachte toekomstige ontwikkelingen}

Het outsourcen van de financiële functie zal zich in de toekomst niet beperken tot concentratie van financiële functies van ondernemingen binnen hetzelfde concernverband. Door de 
gelijksoortigheid van de bedrijfsprocessen laat het zich aanzien dat er Accounting Houses zullen komen die zich richten op het overnemen van de financiële functie van ondernemingen binnen een en dezclfde branche/bedrijfstak, zogenaamde 'horizontale' Accounting Houses. Hicrmee kunnen ook kleinere bedrijven profiteren van de in paragraaf 3 genoemde voordelen die anders uitsluitend aan grotere concerns zouden zijn voorbehouden.

Daarnaast zullen zich zogenaamde "verticale' Accounting Houses ontwikkelen. Doordat in steeds meer bedrijfskolommen wordt gewerkt met 'Supply Chain Management' en 'Just in Time' is de behoefte aan de onderlinge uitwisseling van informatie binnen de keten steeds groter, om de voordelen die zijn verbonden aan ketenintegratie te kunnen realiseren. Een 'service provider' in de vorm van een Accounting House voor de gehcle keten biedt substantiële voordelen ten opzichte van de koppeling van administratief geheel verschillende systemen van de individuele schakels binnen de keten. Bovendien dient er een 'manager" te zijn om tot eenduidig herkenbare informatic in de keten te komen: het Accounting House!

In deze bijdrage hebben wij ons gericht op het outsourcen van de financiële functic in de profitsector. Dat is ook logisch, want de tot nu bekende implementaties van outsourcing hebben in deze sector plaatsgevonden. Het concept om de financiële functie te outsourcen is echter zeer goed toepasbaar in de non-profitsector, waarbij te denken valt aan bijvoorbeeld ziekenhuizen, verzorgingscentra, waterschappen, woningcorporaties, scholen, gemeentes, universiteiten en ambassades. Deze organisaties hebben een geheel andere kernactiviteit en prioriteit dan financial accounting en management accounting, maar deze activiteiten moeten er wel worden verricht. Omdat de organisaties in de non-profitsector per categorie een grote gelijksoortigheid kennen wat betreft de financiële functie, is het aannemelijk dat outsourcing ook hier in de toekomst tot ontwikkeling gaat komen.

\section{Samenvatting en conclusie}

Het outsourcen van de financiële functic is een relatief nieuw fenomeen, waarover steeds meer publicaties verschijnen. Dit artikel is bedoeld als eerste aanzet tot een samenhangend begrippenkader en tot een systematische afweging van de argumenten voor en tegen het outsourcen van de financiële functic. In de meeste publicaties worden de voordelen van outsourcing breed uitgemeten, maar de eerste implementatics van een $\mathrm{AH}$ geven aan dat ondernemingen ook worden geconfronteerd met nadelen van het outsourcen van de financiële functie. Daarom hebben wij in deze bijdrage ook de nadelen besproken die in de praktijk worden ervaren.

De tot nu toe verschenen literatuur is welhaast unaniem in de bevestiging van de kostenvoordelen dic zijn te behalen met outsourcing. Er wordt echter geen duidelijkheid geschapen of het outsourcen van de financiële functie ook daadwerkelijk heeft bijgedragen aan ecn betere financiële ondersteuning van de procesdoclstellingen van de kerncompetenties van de onderneming. Dat zou tot de conclusie kunnen leiden dat outsourcing als een 'ordinaire' bezuinigingsmaatregel wordt gehanteerd, zonder dat er tevens van de gelegenheid gebruik wordt gemaakt om een sprong voorwaarts te maken in de verbetering van de financiële ondersteuning van het ondernemingsbeleid. Dit betekent dat nader onderzock van dit aspect vereist is om het outsourcen van de financiële functie een bredere basis te geven van bewezen argumenten.

\section{LITERATU UR}

Brealey, R.A. en S.C. Myers, (2000), Principles of Corporate Finance, Sixth Edition, McGraw-Hill, Boston.

Dekker, W. en M.J.F. Wouters, (1995), Concentreren van administratieve activiteiten in Europa, Tiidschrift voor Bedrijfsadministratie, januari/februari, pp. 3-7.

Delft Westerhof, M.P. van, (1996), Accounting Houses; Instrument voor verbetering van de financiële functie in een internationale omgeving, Tiidschrift Financieel Management, juli/augustus, pp. 17-22.

Dussauge, P. en B. Garrette, (1999), Cooperative Strategy, John Wiley \& Sons, New York.

Edur, O., (1999), Farm it out!, CMA Management, February, pp. 32-34.

Emmanuel, C., D. Otley en K.A. Merchant, (1998), Accounting for Management Control, Second 
Edition (Reprint), International Thomson Business Press, London.

Fahy, M.J. en M. Donovan, (1999), Shared Service Centres: The Irish Experience, Accountancy Ireland, August, pp. 7-9.

Fisher, L., (1998), A problem shared, Accountancy International, August, pp. 40-41.

Hammer, M. en S. Stanton, (1999), How Process Enterprises Really Work, Harvard Business Review, November/December, pp. 108-118. Heywood, D., (1998), Outsourcing treasury: Making it work, Australian CPA, August, pp. 34-35.

Horn, H.A.L.M. van, (1999a), Accounting House: het einde van de financiële afdeling?, De Accountant, juni, nr. 10, pp. 668-671.

Horn, H.A.L.M. van, (1999b), Haalt de controller het jaar 2000?, Management Control \& Accounting, juni, nr. 3, pp. 40-45.

Horn, H.A.L.M. van, (1999c), Veranderingsmanagement bij Outsourcing Financiële Functie, Tiidschrift Financieel Management, november/ december, pp. 63-76.

Irvine, J., (1998), Onwards and Outwards, Accountancy International, December, pp. 46-47.

Jarman, N., (1998), Shared Service Centres building for Europe, Management Accounting, June, pp. 32-33.

Kersnar, J., (1998), All for one, and one for all, CFO Europe, July/August, p. 12-18.

Keulemans, F. (1998), Outsourcing van een intern audit department, Accountancy en Bedrijfskunde, januari, pp. 21-24.

King, P., P. Leong en E. Durrant, (1998), The road to implementing Shared Service Centres, Management Accounting, September, pp. 32-33.

Kurtz, P. en A. Duncan, (1998), Overcoming resistance to implementation of a shared service centre,
Management Accounting, July/August, pp. 47-48.

Lacity, M.C. en R. Hirschheim, (1995), Beyond The Information Systems Outsourcing Bandwagon, John Wiley \& Sons, New York.

Miller, C., (1999), A look at European Shared Service Centers, Internal Auditor, October, pp. 44-48.

Molenkamp, A., J.W. Verriet en R.M.C. Wijnstekers, (1998), Accounting Houses; Een andere kijk op de financiële functie, Kluwer, Deventer.

Orr, D., (1998), Get it right before you sign, Accountancy International, November, pp. 66-67.

Outram, R., (1999), You will be assimilated, CA Magazine, July, pp. 11-15.

Schellekens, E.H.C., (1999), Hoe efficiënt is uw treasury?, Management Control \& Accounting, januari/februari, nr. 1, pp. 24-28.

Schets, W.F. en Swagerman, D.M., (1998), Financial Shared Service Centers, Tiidschrift Financieel Management, juli/augustus, pp. 31-36.

Schulman, D.S., J.R. Dunleavy, M.J. Harmer en J.S. Lusk, (1999), Shared Services, John Wiley \& Sons, New York

Simons, R., (1999), Performance Measurement \& Control Systems for Implementing Strategy. Prentice Hall, Upper Saddle River.

Singleton-Green, B., (1996), Slipping off the core, Accountancy International, May, p. 50.

Vriend, G.K. de, (1997), Shared Service Centers bij Europese ondernemingen, Controllers Magazine, juni/jul, pp. 52-56. 